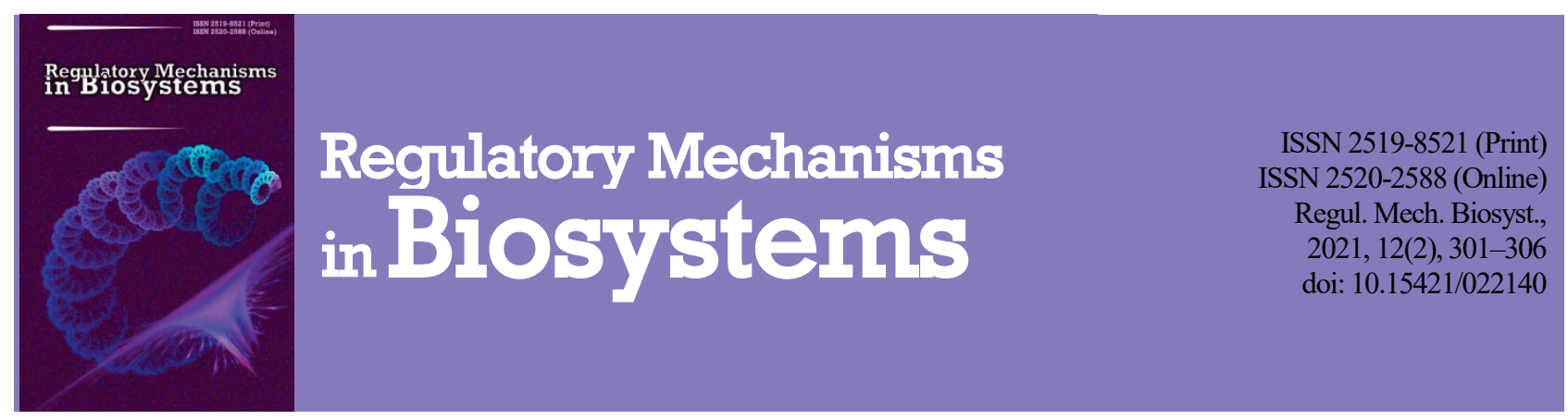

\title{
Retrospective analysis of the control and prevention of tuberculosis among cattle in Ukraine in the period 1994-2020
}

\author{
L. Y. Korniienko*, A. V. Pyskun*, V. V. Ukhovskyi*, M. S. Karpulenko*, \\ O. A. Moroz*, O. O. Pyskun*, T. M. Tsarenko**, G. B. Aliekseieva* \\ *State Scientific and Research Institute of Laboratory Diagnostics and Veterinary and Sanitary Expertise, Kyiv, Ukraine \\ **Bila Tserkva National Agrarian University, Bila Tserkva, Ukraine
}

Article info

Received 01.04.2021

Received in revised form 06.05.202 Accepted 08.05.202

State Scientific and Research Institute of Laboratory Diagnostics and Veterinary and Sanitary Expertise, Donetska st., 30, Kyiv, 03151, Ukraine Tel.: +38-099-415-80-96. E-mail:

anton.pyskun1989@gmail.com

Bila Tserkva National Agrarian University, Soborna st., 8/1, Bila Tserkva, 09117, Ukraine. Tel.: + 38-068-353-63-69.

E-mail:

taras.m.tsarenko@gmail.com
Kornïenko, L. Y., Pyskun, A. V., Ukhovskyi, V. V., Karpulenko, M. S., Moroz, O. A., Pyskun, O. O., Tsarenko, T. M., \& Aliekseieva, G. B. (2021). Retrospective analysis of the control and prevention of tuberculosis among cattle in Ukraine in the period 1994-2020. Regulatory Mechanisms in Biosystems, 12(2), 301-306. doi:10.15421/022140

Bovine tuberculosis (bTB) - is a chronic infectious disease, the causative agent of which affects many species of mammals. It is a zoonosis caused by various types of mycobacteria in the complex Mycobacterium tuberculosis family Mycobacteriaceae. The most important etiological agent of bTB in cattle is $M$. bovis, which has been isolated from tuberculosis infected cattle for centuries. Livestock and species of the Bovidae family are the most susceptible to this pathogen and are the main reservoir species for animals and humans. In Ukraine, the main methods of diagnosing tuberculosis in animal husbandry are lifetime (clinical examination, allergic intradermal test with tuberculin), and postmortem techniques (pathological changes, bacteriological investigation). The authors performed a retrospective analysis of the epizootic situation of tuberculosis among cattle in Ukraine for the period 1994-2020 and conducted a critical assessment of the work done to prevent and control this disease. In total, over the last 27 years, 219088 head of cattle with tuberculosis and 933 affected locations have been identified in Ukraine. The results of this work showed that in our country the epizootic situation of bovine tuberculosis on farms of various forms of ownership is fully controlled. The most active fight against tuberculosis was carried out during 1995-2015. In 1994-1997, the largest number of affected locations was registered, from 90 to 144 , respectively, and the largest number of animals with tuberculosis - 21 395-33 474. In 1994-1995, the largest number of sick animals per one affected point was registered (371.9 and 471.7 head, respectively). Currently, official statistics show that many farms, especially in Vinnytska, Cherkaska and Kyivska regions, continue to show positive allergic reactions to tuberculin (46 898 reactions for the last 12 years). Applying diagnostic methods of research in complex (bacteriological, bioassay, molecular), excludes affection of cattle by pathogenic mycobacteria. This study showed that for the last 5 years no farms with confirmed pathological diagnosis by bacteriological methods have been registered and no culture of the pathogen from animals has been detected. Besides the scurpulous work of the veterinary service, in our opinion, the catastrophic decline in the number of cattle in Ukraine also had a significant impact on improving the epizootic situation regarding tuberculosis.

Keywords: Mycobacterium bovis; bTB; epizootic process; allergic studies; bacteriological studies; mapping.

\section{Introduction}

Bovine tuberculosis (bTB) is a chronic infectious disease, the causative agent of which affects cattle (genus Bos), buffalo (genus Bubalus), bison (genus Bison) and, less frequently, other mammals. It is a zoonosis caused by various types of mycobacteria in the complex Mycobacterium tuberculosis (MTC) family Mycobacteriaceae (Bicout et al., 2017). The most important etiological agents of bTB in cattle are $M$. bovis and, to a lesser extent, $M$. caprae, recognized as an independent mycobacterial species in 2003 (Schiller et al., 2010; Rodriguez-Campos et al., 2014; Nappa et al., 2019). Traditionally, the division of TB pathogens into different species is based on the characteristics of its hosts (phenotypic variations associated with host adaptability and virulence), the identification of human-associated species, and animal-adapted lines with zoonotic potential (Tkachenko et al., 2016). It always coincides with molecular phylogenetics (Brosch et al., 2002; Galagan, 2014; Rodriguez-Campos et al., 2014).

In addition to $M$. bovis and $M$. caprae, other types of MTS complex that have diagnostic value are the following species: $M$. tuberculosis and $M$. africanum - the typical species associated with humans; $M$. canettiithe most divergent within MTS, also isolated from humans; $M$. microtidescribed in the wild rodents; $M$. pinnipedii-described in the seals and sea lions and dassie bacillus - isolated from the mountain shrews (Aranaz et al., 1999; Cousins et al., 2003). In addition, M. mungi from striped mongooses and $M$. suricattae from meerkats, which are closely related to dassie bacillus, as well as $M$. orygi (affects representatives of the family Bovidae - oryx, gazelles, deer, antelope and waterbuck), have recently been characterized (Alexander et al., 2010; van Ingen et al., 2012; Parsons et al., 2013). This group also includes a vaccine strain $M$. bovis Bacillus Calmette and Guérin (BCG) - the only licensed and most widely used vaccine for humans, available since 1921, which provides protective immunity against $M$. tuberculosis exposure (Rodriguez-Campos et al., 2014; Nappa et al., 2019).

Mycobacterium bovis is the most common mycobacterium isolated from tuberculosis-infected cattle for centuries (Pollock \& Neill, 2002; Pérez-Lago, 2014). Livestock and species of the family Bovidae are the most susceptible to this pathogen and are the main reservoir species for animals (Brosch et al., 2002). However, there are some differences in susceptibility between the different subspecies of cattle, in particular Bos taurus and B. indicus (Rodriguez-Campos et al., 2014). The distribution range of $M$. bovis is extremely wide (O'Reilly \& Daborn, 1995; Cousins, 2001). In addition, this pathogen was isolated from other domestic species (pigs, goats, cats, dogs, horses, parrots, etc.) (Michel et al., 2010; Good \& Duignan, 2011; Pesciaroli et al., 2014) and wild animals (camels, wild boars, alpacas, llamas, etc.) (Santos et al., 2009; García-Bocanegra et al., 
2012; Palmer, 2013). Now, it has been established that bovine tuberculosis caused by $M$. bovis can be transmitted from animal to human and, to a lesser extent, from human to animal (Waters et al., 2014; Bicout et al., 2017). Zoonotic tuberculosis clinically and histologically does not differ from human infections caused by M. tuberculosis (O'Reilly \& Daborn, 1995; de la RuaDomenech et al., 2006). In this case, the only way to differentiate these pathogens is to identify isolates to the level of species.

Once bTB enters the herd, it is spread through aerosols and breast milk by direct contact between animals and the combined using of water and feed. Animals with open forms of the disease (release of the pathogen with secretions and excrement) are the most active sources of the pathogen (OIE, 2015). Thus, the leading route of transmission of the pathogen between animals is aerogenic (Domingo et al., 2014). Alimentary infection of animals is also possible, and some researchers indicate that such transmission may even dominate (Serrano et al., 2018). During the disease, the pathological process can be localized in the lungs, udder, genitals, gastrointestinal tract, and the anatomical structure of all these organs and systems contributes to the direct excretion of the pathogen into the environment. Often only the lungs can be affected, and the excretion of mycobacteria, in addition to the respiratory tract, can occur with feces, as sputum containing the pathogen is swallowed and enters in the gastrointestinal tract (Komiienko et al., 2008).

People can be infected by $M$. bovis mostly during consuming unpasteurized milk from infected cows. Livestock farmers, slaughterhouse workers, veterinary workers can also be infected by aerogenic route (Nappa et al., 2019). In regions where sanitation and food hygiene are consistently applied, the risk for the general public is reduced, but zoonotic tuberculosis infection remains an occupational hazard for veterinarians, farmers, slaughterhouse workers and butchers, requiring constant public health monitoring of bTBs (Evans et al., 2007; Gortázar et al., 2015; Olea-Popelka et al., 2017). Human-to-human transmission of $M$. bovis among both immunodeficient (Evans et al., 2007) and immunocompetent patients has also been demonstrated (Sunder et al., 2009; Palacios et al., 2016).

In view of the above, in October 2017, the World Organization for Animal Health (OIE), the World Health Organization (WHO), the Food and Agriculture Organization of the United Nations (FAO) and the International Union against Tuberculosis and Pulmonary Disease (UATLD) have jointly launched the first ever roadmap for control of zoonotic tuberculosis. The map identifies priorities for the control of zoonotic tuberculosis in humans and bovine tuberculosis in animals. Its main provisions are based on the "One Health" approach and are aimed at solving the three most important tasks: 1) improving the base of scientific evidence; 2) reducing the possibility of the pathogen's transmission between animals and humans; 3) strengthening intersectoral cooperation and the development of common approaches (Nappa et al., 2019). This roadmap presupposes the coherence of actions of public institutions, scientists, non-governmental and private organizations and stakeholders at the political, financial and technical levels.

In Ukraine, according to the provisions of the current "Instruction for the prevention and control of animal tuberculosis", the main methods of diagnosing tuberculosis in animal husbandry are lifetime (clinical examination, allergic intradermal test with tuberculin), and postmortem techniques (pathological changes, bacteriological investigation). To identify the epizootic condition of tuberculosis on farms and herds diagnosis of the disease is routinely conducted. On farms unaffected by bTB, scheduled one-time allergic tests are performed in the case of epizootological (epidemiological) indicators and before animals are sold for breeding and production purposes. Breeding stock (cows, bulls, and heifers) is examined twice a year, and all the other livestock - from 40-day age once a year. If an administrative region is fortunate for 4 years or more and there are no tuberculin-responsive animals, all cattle in the region are examined once a year from the age of 40 . On affected farms, one-time allergic tests are performed every $30-45$ days. On not affected farms from affected areas, all livestock are examined twice a year from the 40 days old. The study is also carried out in cases of animals' sale to other farms, 30 days before importation and 25 days from the beginning of preventive quarantine after importation. The epizootic condition of fattening farms is assessed by the results of pathological and anatomical examinations, and veterinary, and sanitary investigation at meat processing plants (Korniienko et al., 2008).
In Ukraine, the diagnosis of bovine tuberculosis is considered established if specific pathological changes are detected in at least one animal during diagnostic slaughter and during bacteriological examination of biological material selected from them with extraction of pathogens M. bovis or M. tuberculosis. The presence of these pathogens is confirmed by biological testing on laboratory animals, PCR, and bacteriological methods. Rehabilitation of livestock farms in Ukraine is carried out through systematic allergic tests, removal of animals that respond positively to tuberculin, and grouping of herds with healthy animals. In addition, the herd can be healed by a complete replacement (in the case of tuberculosis during the year affecting about $15 \%$ of the total population). In the case of receiving two consecutive negative results by allergic tests, such a farm is placed on a 6-month control, during which two negative results should be obtained with an interval of three months. If there are no tuberculin-responsive animals and cattle with clinical forms of tuberculosis in the herd, the farm is considered healthy. Sick animals must be removed from the herd immediately and slaughtered (Korniienko et al., 2008).

Taking into account the epizootic situation regarding this zoonosis in Ukraine, we aimed to conduct a retrospective analysis of measures to control and prevent this disease over the past 27 years (there are complete statistical reports of this disease for this period) to critically assess the achievements and problems in this direction.

\section{Materials and methods}

The authors conducted a retrospective analysis of the epizootic situation regarding bovine tuberculosis in Ukraine in the years 1994-2020. For this purpose we studied, systematized and analyzed the reports of regional laboratories of State Service of Ukraine on Food Safety and Consumer Protection and obtained data of the State Scientific and Research Institute of Laboratory Diagnostics and Veterinary and Sanitary Expertise (SSRILDVSE, Kyiv, Ukraine) (reporting form 2-Vet.) for the 27 year period. In total, 219088 head of cattle with tuberculosis and 933 affected locations by pathogenic mycobacteria (farms of various forms of ownership) have been identified. In addition, article presents the results of allergic (34 839730 head of cattle were investigated) and bacteriological studies (23 548 samples with 806 isolated cultures of mycobacteria).

Numerical data are presented without taking into account the occupied territory of the Autonomous Republic of Crimea, the city of Sevastopol and part of the temporarily occupied territories of Donetsk and Luhansk regions since 2015. Information about the total number of susceptible cattle and farms was obtained from the State Statistics Service of Ukraine (http://ukrstat.gov.ua).

Mapping was presented in the software Quantum GIS 3.16.0 (International Quantum GIS Project, version 2020, Germany), which is free on website (www.qgis.org/ru/site/forusers/download.html). The vector layers for the borders of Ukraine's regions were downloaded from the site www.diva-gis.org/Data. Quantile classification with 5 classes of the data was chosen.

\section{Results}

During the analysis of the obtained data it was established that the largest number of affected locations was registered in 1994 and 1997 ( 90 and 144, respectively). In the same years, the largest number of cattle sick with tuberculosis cattle was registered, respectively, 33474 and 28 749 animals. Over the following years, their number gradually decreased to 54 affected farms and 7388 sick animals in 2005, and in 2010 only 3 farms with 240 infected cattle were registered. Characterizing data from Figure 1, it should be noted that the maximum number of infected animals in one locality was detected in 1995 - 471.7. A significant number of sick animals in one locality were also registered in $1994-371.9$, in 2009 315 , in $2012-311$, and in $2013-323$. A smaller number was registered in 2010 - 80, in 2011 - 63 and since 2015 - 31 animals.

As shown on Figure 1, no sick animals and no affected farms have been detected during the last five years. This is largely due to the removal of the infected animals and the reduction of the total cattle population in Ukraine. Thus, Figure 2 shows a comparison of the reduction in the total number of cattle with the decrease in the number of infected cattle in 
Ukraine during the analyzed period. The analysis of obtained results show that the graphic trends correlate with each other and their clear decrease is observed.

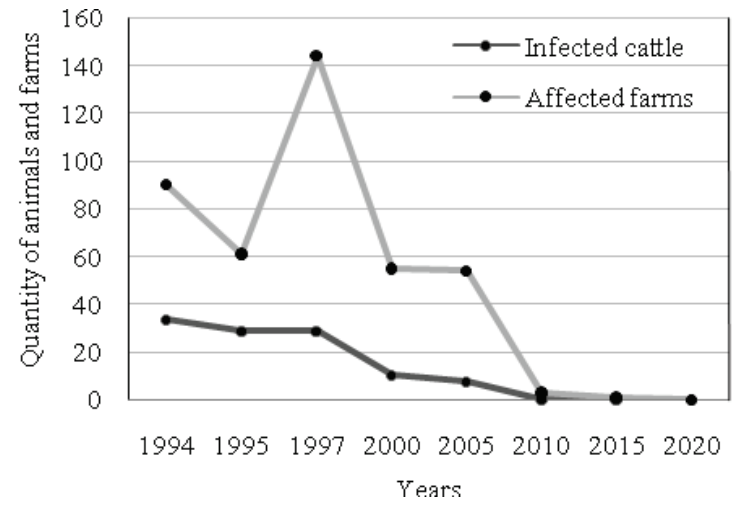

Fig. 1. Dynamics of affected locations and registration of cattle infected by tuberculosis by years (for convenience in the trends comparison, the number of livestock divided by a conventional 1000 units) according to reports of regional laboratories and SSRILDVSE

Since 2009, the number of sick cattle and those removed from the herd and the number of affected farms have decreased rapidly. As shown in Table 1, from 1785300 (2020) to 4308115 (2009) cattle were tested annually during the analyzed period. Generally, about 35 million such tests were conducted. However, it should be noted that the breeding stock was examined twice in accordance with the provisions of the Instruction in force in Ukraine. In addition, over the past 12 years, the number of farms that performed allergic diagnostic tests and the number of animals tested positive to tuberculin have decreased significantly from 4418 points and 6120 animals in 2009 to 1915 points and 990 animals in 2020. Accordingly, the number of farms with tuberculin-responsive animals decreased from 569 to 122 . Below are the data of obtained results of allergic and bacteriological tests, diagnostic slaughter, etc. (Table 1).

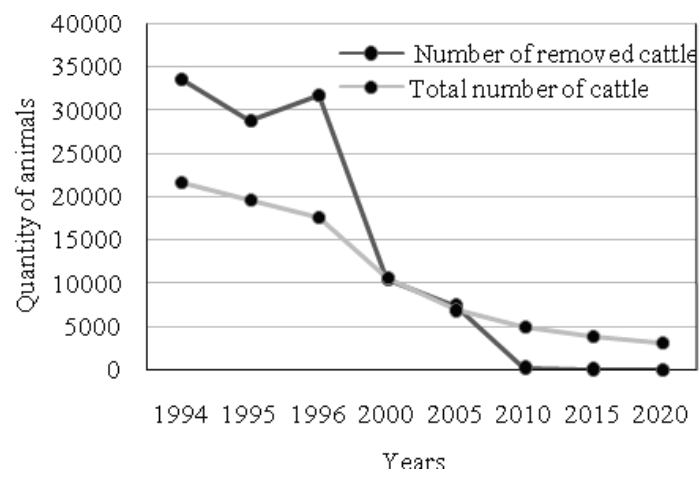

Fig. 2. Dynamics of cattle removed from the herd due to tuberculosis infection (for convenience in the trends comparison, the total number of livestock divided by a conventional 1000 units) according to reports

of regional laboratories and SSRILDVSE for 1994-2020 years

The density of the number of conducted allergy tests and cattle identified as positively responding in terms of regions of Ukraine is quite significant for the analyzed period. As shown on Figure 3a, the largest number of allergy tests was mainly in the central and northern regions of Ukraine: Poltavska (4 440212 studies), Cherkaska (2 458 128), Chernihivska (1 994 467), Vinnytska (1 979854 studies) regions etc. At the same time, positive reactions to tuberculin were mainly registered in animals from Vinnytska (8 976), Cherkaska (7 548), and Kyivska (4 841) regions (Fig. 3b).

\section{Table 1}

Systematized results of complex diagnostics of bovine tuberculosis in Ukraine according to reports of regional laboratories and SSRILDVSE

\begin{tabular}{|c|c|c|c|c|c|c|c|c|}
\hline \multirow[b]{2}{*}{ Years } & \multicolumn{2}{|c|}{ Allergy tests } & \multicolumn{2}{|c|}{ Positive reactions } & \multicolumn{2}{|c|}{ The diagnostic slaughtered animals and results } & \multirow{2}{*}{$\begin{array}{l}\text { Number of farms } \\
\text { with confirmed } \\
\text { diagnosis }\end{array}$} & \multirow{2}{*}{$\begin{array}{l}\text { Isolated cul- } \\
\text { tures } M \text {. bovis } \\
\text { (culture/farms) }\end{array}$} \\
\hline & $\begin{array}{l}\text { number } \\
\text { of cattle }\end{array}$ & $\begin{array}{l}\text { number } \\
\text { of farms }\end{array}$ & $\begin{array}{l}\text { number } \\
\text { of cattle }\end{array}$ & $\begin{array}{l}\text { number } \\
\text { of farms }\end{array}$ & $\begin{array}{l}\text { number of diagnostic } \\
\text { slaughtered animals }\end{array}$ & $\begin{array}{c}\text { detected with pathological } \\
\text { changes (cattle/farms) }\end{array}$ & & \\
\hline 2009 & 4308115 & 4418 & 6120 & 569 & 758 & $28 / 2$ & 1 & $12 / 2$ \\
\hline 2010 & 4044397 & 3666 & 8823 & 691 & 1095 & $12 / 2$ & 5 & $10 / 3$ \\
\hline 2011 & 3774447 & 3438 & 7789 & 523 & 907 & $11 / 3$ & 3 & - \\
\hline 2012 & 3475602 & 3228 & 5027 & 411 & 694 & $10 / 2$ & 1 & - \\
\hline 2013 & 3352494 & 3122 & 5071 & 379 & 628 & $5 / 1$ & 1 & $1 / 1$ \\
\hline 2014 & 3065137 & 2585 & 3407 & 309 & 506 & $1 / 1$ & - & $1 / 1$ \\
\hline $2015^{*}$ & 2678485 & 2582 & 2915 & 279 & 443 & $22 / 1$ & 1 & $5 / 1$ \\
\hline $2016^{*}$ & 2000026 & 2263 & 1988 & 221 & 338 & $-1-$ & - & - \\
\hline $2017 *$ & 2284687 & 2301 & 1857 & 193 & 343 & $-1-$ & - & - \\
\hline $2018 *$ & 1960365 & 5109 & 1525 & 192 & 230 & $-1-$ & - & - \\
\hline $2019 *$ & 2110675 & 2061 & 1386 & 161 & 260 & $1 / 1$ & - & - \\
\hline $2020^{*}$ & 1785300 & 1915 & 990 & 122 & 191 & $-1-$ & - & - \\
\hline Total & 34839730 & 36688 & 46898 & 4050 & 6393 & $90 / 12$ & 12 & $29 / 8$ \\
\hline
\end{tabular}

Note: * marks parameters presented without taking into account the occupied territory of the Autonomous Republic of Crimea, the city of Sevastopol and part of the temporarily occupied territories of Donetsk and Luhansk regions.
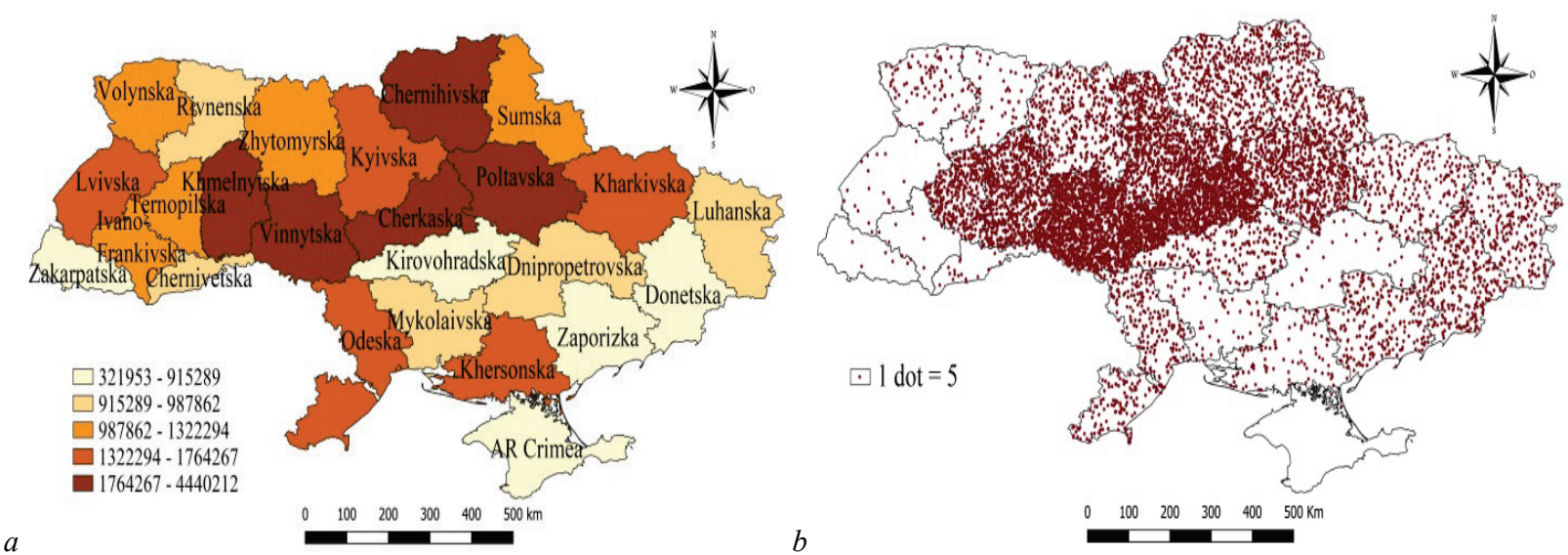

Fig. 3. Map-scheme of the allergy test results among cattle in Ukraine during 2009-2020: $a$ - density of tests, $b$ - density of positive reactions 
During this period, the number of diagnostic slaughtered livestock ranged from 1095 in 2010 to 191 - in 2020 . In the same years, the total number of slaughtered animals was 4770 and 653 animals, respectively, on average, one diagnostic slaughter accounted for 4.4 and 3.4 head. Over the past 5 years, pathological changes have been detected in only one animal in 2019. In general, during the analyzed period, the largest number of cattle with pathological changes was found in 2009 and 2015 (28 and 22 animals, respectively). The last isolation of $M$. bovis cultures from pathological material with bacteriological confirmation was in 2015 (5 positive examinations from the one farm). The last case of detection of carcasses with pathological changes inherent for bovine tuberculosis was recorded on the meat-packing plant conveyor according to the "Signal" system in 2010 ( 2 carcasses).
Regarding the laboratory diagnosis of tuberculosis, 23548 samples from 3847 farms were subjected to bacteriological studies by veterinary specialists during the last 12 years (pathological materials from 676 to 4309 animals were investigated annually). The number of farms diagnosed by a comprehensive method ranged from 114 (2019) to 406 (2010). The total number of such farms during the analyzed period was 2856 . The materials of Table 2 show the constant work of laboratory specialists in the direction of typing mycobacteria cultures isolated during post-mortem bacteriological studies. Thus, during the analyzed period, from 17 (2019) to 158 (2011) cultures were isolated. The smallest number of farms in which the cultures of these microorganisms were isolated from animal materials was registered in 2020 (10 farms), and the largest in $2011-83$. In total, 806 cultures of mycobacteria from 455 affected farms were isolated.

\section{Table 2}

Data obtained as a result of bacteriological studies of pathological materials from cattle tested for tuberculosis in Ukraine according to reports of regional laboratories and SSRILDVSE

\begin{tabular}{|c|c|c|c|c|c|c|c|c|c|}
\hline \multirow{3}{*}{ Years } & \multirow{2}{*}{\multicolumn{2}{|c|}{ Bacteriology and bioassay }} & \multirow{3}{*}{$\begin{array}{c}\text { Number } \\
\text { of farms } \\
\text { with complex } \\
\text { diagnosis }\end{array}$} & \multicolumn{6}{|c|}{ Isolated cultures } \\
\hline & & & & \multirow{2}{*}{$\begin{array}{l}\text { total } \\
\text { number }\end{array}$} & \multirow{2}{*}{$\begin{array}{l}\text { from } \\
\text { farms }\end{array}$} & \multicolumn{4}{|c|}{ species of mycobacteria } \\
\hline & $\begin{array}{c}\text { number } \\
\text { of samples }\end{array}$ & $\begin{array}{l}\text { number } \\
\text { of farms }\end{array}$ & & & & $\begin{array}{l}\text { M. tuberculosis, } \\
\text { culture / farms }\end{array}$ & $\begin{array}{c}\text { M. bovis, } \\
\text { culture/farms }\end{array}$ & $\begin{array}{c}\text { M. avium, } \\
\text { culture / farms }\end{array}$ & $\begin{array}{c}\text { atypical, } \\
\text { culture / farms }\end{array}$ \\
\hline 2009 & 3122 & 518 & 298 & 68 & 22 & 0 & $12 / 2$ & $1 / 1$ & $55 / 20$ \\
\hline 2010 & 4309 & 600 & 406 & 136 & 80 & 0 & $10 / 3$ & $1 / 1$ & $125 / 78$ \\
\hline 2011 & 3523 & 478 & 402 & 158 & 83 & $1 / 1$ & 0 & 0 & $157 / 82$ \\
\hline 2012 & 2393 & 401 & 350 & 108 & 64 & 0 & 0 & 0 & $108 / 64$ \\
\hline 2013 & 2164 & 378 & 282 & 57 & 38 & 0 & $1 / 1$ & 0 & $56 / 37$ \\
\hline 2014 & 1697 & 300 & 223 & 61 & 34 & 0 & $1 / 1$ & 0 & $60 / 34$ \\
\hline $2015 *$ & 1666 & 304 & 233 & 57 & 24 & 0 & $5 / 1$ & 0 & $52 / 23$ \\
\hline $2016^{*}$ & 1167 & 214 & 152 & 45 & 31 & 0 & 0 & 0 & $45 / 31$ \\
\hline $2017 *$ & 1154 & 199 & 146 & 50 & 33 & 0 & 0 & 0 & $50 / 33$ \\
\hline $2018 *$ & 841 & 157 & 126 & 28 & 15 & 0 & 0 & 0 & $28 / 15$ \\
\hline $2019 *$ & 836 & 160 & 114 & 17 & 21 & 0 & 0 & 0 & $17 / 21$ \\
\hline $2020 *$ & 676 & 138 & 124 & 21 & 10 & 0 & 0 & 0 & $21 / 10$ \\
\hline Total: & 23548 & 3847 & 2856 & 806 & 455 & $1 / 1$ & $29 / 8$ & $2 / 2$ & $774 / 446$ \\
\hline
\end{tabular}

Note: * marks parameters presented without taking into account the occupied territory of the Autonomous Republic of Crimea, the city of Sevastopol and part of the temporarily occupied territories of Donetsk and Luhansk regions.

During the typing of the pathogen, the human type (M. tuberculosis) was isolated from only one animal in 2011. The cultures of $M$. bovis were isolated in 2009 - 12 cultures from 2 farms, in 2010 - 10 cultures from 3 farms, in 2013 and 2014 - one culture from one farm, and in 2015 5 cultures from one farm. Generally, 29 cultures of M. bovis from eight farms of Ukraine were isolated during these years. $M$. avium was isolated in 2009 and 2010 - one culture from one farm. Systematized materials of our research indicate that the human type has not been isolated during bacteriological studies since 2012, bovine - since 2016, and avian - since 2011. Atypical mycobacteria were isolated annually. In addition, as can be seen from the materials of Table 2, during the last 5 years only these forms were isolated. The largest number of these microorganisms was isolated in $2011-157$ cultures from 82 farms. Their smallest number was allocated in the last 5-7 years. In total, 774 cultures of atypical mycobacteria were isolated from 446 farms over the last 27 years.

\section{Discussion}

Currently, bovine tuberculosis is registered worldwide, however, at the same time, there are countries in which there have been no confirmed diagnoses of this disease. Many developed countries have either completely eradicated the disease or significantly limited its spread through effective prevention and control measures. In particular, based on the concept of "One Health" in 2016-2017, a roadmap for zoonotic tuberculosis was developed, which combined the efforts of OIE, WHO, and FAO specialists (Nappa et al., 2019). It emphasized the relationship between human and animal health and identified an overall strategy and priority actions in the fight against tuberculosis (Good et al., 2018). The highest prevalence of tuberculosis among cattle is observed in Africa and some parts of Asia. The disease is also registered in some countries in Europe and the USA (Waters et al., 2014; Good et al., 2018). Since the first half of the twentieth century, especially in high-income countries, bTB eradication programs have been introduced with the introduction of enhanced food safety measures, which have significantly limited the spread of the pathogen in cattle herds and among humans (Zinsstag et al., 2006; Good et al., 2018). As for
Ukraine, the epizootic situation of bovine tuberculosis on farms under various forms of ownership is completely under control. Thus, our study has shown that it has improved significantly in recent years. The most active measures against tuberculosis in our country were carried out during 1995-2015. In 1994-1997, the largest number of affected locations was registered, from 90 to 144, respectively, and the largest number of animals with tuberculosis - 21 395-33 474. In 1994-1995, the largest number of sick animals per one affected point was registered (371.9 and 471.7 heads, respectively). Currently, official statistics show that many farms, especially in Vinnytska, Cherkaska, and Kyivska regions, continue to show positive allergic reactions to tuberculin (46 898 reactions over the past 12 years) and, using comprehensive diagnostic methods (bacteriological, bioassay, molecular), exclude infection of livestock by pathogenic mycobacteria.

However, investigation regarding the possible circulation of tuberculosis pathogens among wildlife in Ukraine has not been conducted. This can significantly complicate the complete eradication of this zoonosis in our country, because, according to the literature, there are natural foci of infection in other countries (Good \& Duignan, 2011; Waters et al., 2014). Other domestic species may also be reservoir species of bTB (Pesciaroli et al., 2014). Thus, goats are quite susceptible to this pathogen (de Val et al., 2011) and some researchers suggest that they may be reservoir species (Napp et al., 2013; Zanardi et al., 2013). Sheep are a species that is less susceptible than cattle and goats, but a significant number of reports indicate their reservoir role too (Mendoza et al., 2012; Broughan et al., 2013; Mendoza et al., 2016). In addition, scientists suggest a possible reservoir role of pigs in maintaining bTB (Di Marco et al., 2012; Amato et al., 2018). Thus, studies of strains and their characteristics have shown that the same strains of $M$. bovis can circulate in domestic pigs, wild boars and cattle (Parra et al., 2003; Bailey et al., 2013). The role of alpacas and llamas in the infectious process has been proved (Twomey et al., 2007; García-Bocanegra et al., 2012). Regarding morbidity among humans, zoonotic tuberculosis in the world remains unstudied (Olea-Popelka et al., 2017). Reports are often unrepresentative, and information may be misunderstood due to certain technical limitations, such as difficulty differen- 
tiating M. tuberculosis from M. bovis or M. caprae. Such differentiation requires the isolation of mycobacteria on selective nutrient media with their subsequent identification by using biochemical tests or molecular diagnostic methods (for example, different genotyping methods) that may be unavailable or not used (Müller et al., 2013). The human tuberculosis epidemic in Ukraine was declared in 1995 (Feshchenko \& Cherenko, 2012). The leading pathogen among humans in Ukraine is M. tuberculosis, but if pathogens of bovine or avian species are isolated during laboratory tests, they are referred to as "mycobacteriosis" or "non-tuberculous mycobacteria" (NTMB). Statistics of such diagnostic research in our country are not conducted (Zhurilo et al., 2020). Thus, we cannot know the exact number of people affected by $M$. bovis in Ukraine.

The improvement of the epizootic situation regarding tuberculosis in Ukraine is connected with the constant and scrupulous implementation of measures by the veterinary medicine service and the administration of farms (animal owners) to prevent and control this disease. This is especially noticeable after implementation of "Instruction for the prevention and control of tuberculosis in animals" in 2009. This investigation showed that during the last 5 years no farms with confirmed pathological diagnosis by bacteriological methods have been registered and no cultures of the pathogen from animals have been detected. In addition, the number of responding animals during routine diagnostic allergic tests was significantly reduced. At the same time, over a 12-year period, the number of tests and the number of farms in which such tests were conducted decreased significantly (respectively, in 2.4 and 2.3 times).

Besides the painstaking work of the veterinary service, in our opinion, the catastrophic decline in the number of cattle in Ukraine also had a significant impact on improving the epizootic situation regarding tuberculosis. Thus, it can be concluded that the trends of cattle the removed from herds due to tuberculosis for the period 1994-2020 on farms of different forms of ownership coincide with the trend of declining number of cattle in our country. The greatest number of positive reactions regarding tuberculosis correlated with the presence of a significant number of cattle on farms. The intensity of the epizootic situation had significantly decreased by 2009. By this time, the number of cattle had decreased more than 4 times to 5079 thousand head compared to 1994 (21 607 thousand head).

\section{Conclusions}

Analysis of the epizootic and bacteriological studies regarding tuberculosis among cattle shows a significant tendency to reduction in the number of positive cases. Thus, M. tuberculosis (human type) was last isolated from cattle in 2011, M. bovis - in 2015, M. avium - in 2010. In contrast to pathogenic mycobacteria, atypical forms of the pathogen are isolated annually throughout the analyzed period. This investigation showed that over the last 5 years no farms with confirmed pathological diagnosis by bacteriological methods have been registered and no cultures of the pathogen from animals have been detected. In addition, the number of responding animals during routine diagnostic allergy tests was significantly reduced. At the same time, over a 12-year period, the number of tests and the number of farms in which such tests were conducted decreased significantly (respectively, in 2.4 and 2.3 times).

Besides the scrupulous anti-tuberculosis work of the veterinary service, in our opinion, the catastrophic reduction of livestock had a significant impact on the recovery of Ukrainian livestock from tuberculosis and a reduction in affected farms. After all, extensive technologies, lack of profitability and profits, low productivity, unbundling and corporatization of collective farms led to the fact that cattle simply began to be slaughtered for economic reasons. Cattle from farms where animals were found to be sick or suspected of tuberculosis infection were slaughtered first.

The authors would like to express their gratitude to the specialists of State Service of Ukraine on Food Safety and Consumer Protection and the State Laboratories of Veterinary Medicine in the regions for presenting the official reports and for assistance.

\section{References}

Alexander, K. A., Laver, P. N., Michel, A. L., Williams, M., van Helden, P. D., Warren, R. M., \& Gey van Pittius, N. C. (2010). Novel Mycobacterium tuberculosis complex pathogen $M$. mungi. Emerging Infectious Diseases, 16(8), 1296-1299.

Amato, B., Di Marco Lo Presti, V., Gerace, E., Capucchio, M. T., Vitale, M., Zanghi, P., \& Boniotti, M. B. (2018). Molecular epidemiology of Mycobacterium tuberculosis complex strains isolated from livestock and wild animals in Italy suggests the need for a different eradication strategy for bovine tuberculosis. Transboundary and Emerging Diseases, 65(2), 416-424.

Aranaz, A., Liébana, E., Gómez-Mampaso, E., Galán, J. C., Cousins, D., Ortega, A. Blázquez, J., Baquero, F., Mateos, A., Súarez, G., \& Domínguez, L. (1999). Mycobacterium tuberculosis subsp. caprae subsp. nov.: A taxonomic study of a new member of the Mycobacterium tuberculosis complex isolated from goats in Spain. International Joumal of Systematic Bacteriology, 49(3), 1263-1273.

Bailey, S. S., Crawshaw, T. R., Smith, N. H., \& Palgrave, C. J. (2013). Mycobacterium bovis infection in domestic pigs in Great Britain. Veterinary Journal, 198(2), 391-397.

Bicout, D., Bøtner, A., Butterworth, A., Calistri, P., Depner, K., Edwards, S., GarinBastuji, B., Good, M., Schmidt, G. C., Michel, V., Miranda, M. A., More, S., Nielsen, S. S., Raj, M., Sihvonen, L., Spoolder, H., Stegeman, J. A., Thulke, H. H., Velarde, A., Willeberg, P., \& Winckler, C. (2017). Panel on animal health and welfare (EFSA AHAW). Assessment of listing and categorisation of animal diseases within the framework of the Animal Health Law (Regulation (EU) No 2016/429): Bovine tuberculosis. EFSA Journal, 15(8), 4959.

Brosch, R., Gordon, S. V., Marmiesse, M., Brodin, P., Buchrieser, C., Eiglmeier, K., \& Cole, S. T. (2002). A new evolutionary scenario for the Mycobacterium tuberculosis complex. Proceedings of the National Academy of Sciences of the United States of America, 99(6), 3684-3689.

Broughan, J. M., Crawshaw, T. R., Downs, S. H., Brewer, J., \& Clifton-Hadley, R. S. (2013). Mycobacterium bovis infections in domesticated non-bovine mammalian species. Part 2: A review of diagnostic methods. Veterinary Journal, 198(2), 346-351.

Cousins, D. V. (2001). Mycobacterium bovis infection and control in domestic livestock. Revue Scientifique et Technique-Office International des Epizooties, 20(1), 71-85.

Cousins, D. V., Bastida, R., Cataldi, A., Quse, V., Redrobe, S., Dow, S., Duignan, P., Murray, A., Dupont, C., Ahmed, N., Collins, D. M., Butler, W. R., Dawson, D., Rodríguez, D., Loureiro, J., Romano, M. I., Alito, A., Zumarraga, M., \& Bernardelli, A. (2003). Tuberculosis in seals caused by a novel member of the $M y$ cobacterium tuberculosis complex: Mycobacterium pinnipedii sp. nov. International Journal of Systematic and Evolutionary Microbiology, 53(5), 1305-1310.

de la Rua-Domenech, R., Goodchild, A. T., Vordermeier, H. M., Hewinson, R. G., Christiansen, K. H., \& Clifton-Hadley, R. S. (2006). Ante mortem diagnosis of tuberculosis in cattle: A review of the tuberculin tests, gamma-interferon assay and other ancillary diagnostic techniques. Research in Veterinary Science, 81(2), 190-210

De Val, P. B., López-Soria, S., Nofrarías, M., Martín, M., Vordermeier, H. M., Ramos, V. B., \& Domingo, M. (2011). Experimental model of tuberculosis in the domestic goat after endobronchial infection with Mycobacterium caprae. Clinical and Vaccine Immunology, 18(11), 1872-1881.

Di Marco, V., Mazzone, P., Capucchio, M. T., Boniotti, M. B., Aronica, V., Russo, M., Fiasconaro, M., Cifani, N., Comeli, S., Biasibetti, E., Biagetti, M., Pacciarini, M. L., Cagiola, M., Pasquali, P., \& Marianelli, C. (2012). Epidemiological significance of the domestic black pig (Sus scrofa) in maintenance of bovine tuberculosis in Sicily. Journal of Clinical Microbiology, 50(4), 1209-1218.

Domingo, M., Vidal, E., \& Marco, A. (2014). Pathology of bovine tuberculosis. Research in Veterinary Science, 97, 20-29.

Evans, J. T., Smith, E. G., Banerjee, A., Smith, R. M., Dale, J., Innes, J. A., Hunt, D., Tweddell, A., Wood, A., Anderson, C., Hewinson, R. G., Smith, N. H., Hawkey, P. M., \& Sonnenberg, P. (2007). Cluster of human tuberculosis caused by Mycobacterium bovis: Evidence for person-to-person transmission in the UK. Lancet, 369(9569), 1270-1276.

Feshchenko, Y. I., \& Cherenko, S. A. (2012). Epidemija tuberkulozu v Ukrajini: Istorychni aspekty ta suchasnyj stan problemy [Epidemic of tuberculosis in Ukraine. Historical aspects and the current state of the problem]. Scientific Journal of Ministry of Health of Ukraine, 1(1), 48-57 (in Ukrainian).

Galagan, J. E. (2014). Genomic insights into tuberculosis. Nature Reviews. Genetics, $15(5), 307-320$.

García-Bocanegra, I., de Val, B. P., Arenas-Montes, A., Paniagua, J., Boadella, M., Gortázar, C., \& Arenas, A. (2012). Seroprevalence and risk factors associated to Mycobacterium bovis in wild artiodactyl species from Southern Spain, 20062010. PLoS One, 7, 34908.

Good, M., \& Duignan, A. (2011). Perspectives on the history of bovine TB and the role of tuberculin in bovine TB eradication. Veterinary Medicine International, 2011,410470 . 
Good, M., Bakker, D., Duignan, A., \& Collins, D. M. (2018). The history of in vivo tuberculin testing in bovines: Tuberculosis, a - One Health. Frontiers in Veterinary Science, 5,59 .

Gortázar, C., Che, A. A., \& O‘Brien, D. J. (2015). Open questions and recent advances in the control of a multi-host infectious disease: Animal tuberculosis: Recent advances in animal tuberculosis control. Mammal Review, 45(3), 160-175.

Komiienko, L. Y., Busol, V. O., Nedosiekov, V. V., Kucheriavenko, O. O., Kucheriavenko, O. O., \& Komiienko, L. M. (2008). Khronichni infektsijni khvoroby tvaryn [Chronic infectious diseases in animals]. BNAU, Bila Tserkva (in Ukrainian).

Mendoza, M. M., de Juan, L., Menéndez, S., Ocampo, A., Mourelo, J., Sáez, J. L., Domínguez, L., Gortázar, C., Garcia-Marín, J. F., \& Balseiro, A. (2012). Tuberculosis due to Mycobacterium bovis and Mycobacterium caprae in sheep. Veterinary Joumal, 191(2), 267-269.

Mendoza, M. M., Romero, B., Del Cerro, A., Gortázar, C., García-Marín, J. F., Menéndez, S., \& Balseiro, A. (2016). Sheep as a potential source of bovine TB: Epidemiology, pathology and evaluation of diagnostic techniques. Transboundary and Emerging Diseases, 63(6), 635-646.

Michel, A. L., Müller, B., \& van Helden, P. D. (2010). Mycobacterium bovis at the animal - human interface: A problem, or not? Veterinary Microbiology, 140, 371-381.

Müller, B., Dürr, S., Alonso, S., Hattendorf, J., Laisse, C. J. M., Parsons, S. D., \& Zinsstag, J. (2013). Zoonotic Mycobacterium bovis-induced tuberculosis in humans. Emerging Infectious Diseases, 19(6), 899-908.

Napp, S., Allepuz, A., Mercader, I., Nofrarías, M., López-Soria, S., Domingo, M., \& de Val, P. B. (2013). Evidence of goats acting as domestic reservoirs of bovine tuberculosis. The Veterinary Record, 172(25), 663.

Nappa, S., Ciaravino, G., de Val, B. P., Casala, J., Saéz, J. L., \& Alba, A. (2019). Evaluation of the effectiveness of the surveillance system for tuberculosis in cattle in Spain. Preventive Veterinary Medicine, 173, 104805.

O'Reilly, L. M., \& Daborn, C. J. (1995). The epidemiology of Mycobacterium bovis infections in animals and man: A review. Tubercle and Lung Disease, 76(1), 1-46.

Olea-Popelka, F., Muwonge, A., Perera, A., Dean, A. S., Mumford, E., ErlacherVindel, E., \& Fujiwara, P. I. (2017). Zoonotic tuberculosis in human beings caused by Mycobacterium bovis - a call for action. The Lancet, Infectious Diseases, 17(1), 21-25.

Palacios, J. J., Navarro, Y., Romero, B., Penedo, A., González, Á. M., Hernández, D. P., Fernández-Verdugo, A., Copano, F., Torreblanca, A., Bouza, E., Domínguez, L., de Juan, L., \& de Viedma, D. G. (2016). Molecular and epidemiological population-based integrative analysis of human and animal Mycobacterium bovis infections in a low-prevalence setting. Veterinary Microbiology, 195, 30-36.

Palmer, M. V. (2013). Mycobacterium bovis: Characteristics of wildlife reservoir hosts. Transboundary and Emerging Diseases, 60(1), 1-13.

Parra, A., Fernandez-Llario, P., Tato, A., Larrasa, J., Garcia, A., Alonso, J. M., \& de Mendoza, J. H. (2003). Epidemiology of Mycobacterium bovis infections of pigs and wild boars using a molecular approach. Veterinary Microbiology, 97, 123-133.

Parsons, S. D., Drewe, J. A., Gey van Pittius, N. C., Warren, R. M., \& van Helden, P. D. (2013). Novel cause of tuberculosis in meerkats, South Africa. Emerging Infectious Diseases, 19(12), 2004-2007.

Pérez-Lago, L., Navarro, Y., \& de Viedma, G. D. (2014). Current knowledge and pending challenges in zoonosis caused by Mycobacterium bovis: A review. Research in Veterinary Science, 97, 94-100.
Pesciaroli, M., Alvarez, J., Boniotti, M. B., Cagiola, M., Di Marco, V., Marianelli, C., \& Pasquali, P. (2014). Tuberculosis in domestic animal species. Research in Veterinary Science, $97,78-85$.

Pollock, J. M., \& Neill, S. D. (2002). Mycobacterium bovis infection and tuberculosis in cattle. Veterinary Journal, 163(2), 115-127.

Rodriguez-Campos, S., Smith, N. H., Boniotti, M. B., \& Aranaz, A. (2014). Overview and phylogeny of Mycobacterium tuberculosis complex organisms: Implications for diagnostics and legislation of bovine tuberculosis. Research in Veterinary Science, 97, 5-19.

Santos, N., Correia-Neves, M., Ghebremichael, S., Källenius, G., Svenson, S. B., \& Almeida, V. (2009). Epidemiology of Mycobacterium bovis infection in wild boar (Sus scrofa) from Portugal. Joumal of Wildlife Diseases, 45(4), 1048-1061.

Schiller, I., Oesch, B., Vordermeier, H. M., Palmer, M. V., Harris, B. N., Orloski, K. A., \& Waters, W. R. (2010). Bovine tuberculosis: A review of current and emerging diagnostic techniques in view of their relevance for disease control and eradication. Transboundary and Emerging Diseases, 57(4), 205-220.

Serrano, M., Sevilla, I. A., Fuertes, M., Geijo, M., Risalde, M. Á., Ruiz-Fons, J. F., \& Garrido, J. M. (2018). Different lesion distribution in calves orally or intratracheally challenged with Mycobacterium bovis: Implications for diagnosis. Veterinary Research, 49(1), 74.

Sunder, S., Lanotte, P., Godreuil, S., Martin, C., Boschiroli, M. L., \& Besnier, J. M. (2009). Human-to-human transmission of tuberculosis caused by Mycobacterium bovis in immunocompetent patients. Joumal of Clinical Microbiology, 47(4), 1249-1251.

Tkachenko, A. A., Davydenko, P. O., Zazharskiy, V. V., \& Brygadyrenko, V. V. (2016). Biological properties of dissociative L- and other forms of Mycobacterium bovis. Visnyk of Dnipropetrovsk University, Biology, Ecology, 24(2), 338-346.

Twomey, D. F., Crawshaw, T. R., Anscombe, J. E., Farrant, L., Evans, L. J., McElligott, W. S., \& de la Rua-Domenech, R. (2007). TB in llamas caused by Mycobacterium bovis. The Veterinary Record, 160(5), 170.

van Ingen, J., Rahim, Z., Mulder, A., Boeree, M. J., Simeone, R., Brosch, R., \& van Soolingen, D. (2012). Characterization of Mycobacterium orygis as M. tuberculosis complex subspecies. Emerging Infectious Diseases, 18(4), 653-655.

Waters, W. R., Maggioli, M. F., McGill, J. L., Lyashchenko, K. P., \& Palmer, M. V. (2014). Relevance of bovine tuberculosis research to the understanding of human disease: Historical perspectives, approaches, and immunologic mechanisms. Veterinary Immunology and Immunopathology, 159(3-4), 113-132.

World Organization for Animal Health (2015). Chapter 2.4.7: Bovine tuberculosis. In: Cousins, D. V. (Ed.). Manual of diagnostic tests and vaccines for terrestrial animals. 8th edition. Bentley Delivery Center, Bentley. Pp. 1113-1124.

Zanardi, G., Boniotti, M. B., Gaffuri, A., Casto, B., Zanoni, M., \& Pacciarini, M. L. (2013). Tuberculosis transmission by Mycobacterium bovis in a mixed cattle and goat herd. Research in Veterinary Science, 95(2), 430-433.

Zhurilo, O. A., Barbova, A. I., \& Sladkova, L. M. (2020). Mycobacterium avium as pathogen of human mycobacteriosis. Ukrainian Pulmonology Joumal, 1, 50-58.

Zinsstag, J., Schelling, E., Roth, F., \& Kazwala, R. (2006). Economics of bovine tuberculosis. In Mycobacterium bovis Infection in Animals and Humans. 2nd edition. Blackwell Publishing Ltd., Oxford. Pp. 68-83. 